\title{
ANALISIS SWOT SEBAGAI STRATEGI MENINGKATKAN KEUNGGULAN PADA UD. KACANG SARI DI DESA TAMBLANG
}

\author{
I Gusti Nyoman Alit Brahma Putra \\ Jurusan Pendidikan Ekonomi \\ Universitas Pendidikan Ganesha \\ Singaraja, Indonesia \\ e-mail: alitbrahma@gmail.com
}

\begin{abstract}
Abstrak
Penelitian ini bertujuan untuk mengetahui 1) kekuatan dan kelemahan yang dihadapi oleh UD. Kacang sari, 2) ancaman dan peluang yang dihadapi oleh UD. Kacang Sari, dan 3) alternatif strategi apa yang bisa diambil dalam menghadapi persaingan bisnis di UD. Kacang Sari. Penelitian ini menggunakan rancangan peneltitan deskriptif. Data yang dikumpulkan dengan menggunakan metode wawancara dan observasi dianalisis menggunakan analisis SWOT. Hasil penelitian ini menunjukan bahwa kekuatan memiliki nilai total sebesar 1,40 berbanding kelemahan sebesar 0,70 . Posisi perusahaan terhadap lingkungan di luar juga memiliki posisi yang kuat dimana peluang perusahaan memiliki nilai total sebesar 2,30 berbanding kelemahan sebesar 0,70. Dilihat dari nilai total dimana kekuatan sebesar 1,40 lebih kecil dari peluang 2,30 berdasarkan kuadran SWOT maka pilihan alternatif strategi yang bisa diambil adalah strategi Stable Growth.
\end{abstract}

Kata kunci: Kekuatan,kelemahan,ancaman, dan peluang (SWOT).

\begin{abstract}
This report aims to understand 1 ) strength and weakness facing UD.Nut cider, 2 ) threats and opportunities facing UD.Nut cider, and 3 strategies will ) alternative that can be taken in the face of business competition in UD.Nut cider.This research using peneltitan descriptive design. The data collected by using the method interviews and observation analyzed using analysis the internal factor and analysis external factors The result of this research showed that the power of having the value of the total $r p 1.40$ compared to weakness of 0,70 .The position of the company to the environment out too having their position of power where having the value of the company total rp $0,702.30$ compared to weakness as much as. Seen from total where force amounting to 1,40 smaller of opportunities 2,30 based on quadrant training and alternative choices for the strategy that can be taken is stable growth strategy.
\end{abstract}

Keywords: the power, weakness, threat, training and opportunities (SWOT).

\section{PENDAHULUAN}

Persaingan dalam dunia usaha dewasa ini tampak meningkat. Hal ini menyebabkan setiap perusahaan mendapat tantangan untuk berusaha menghadapi pesaing. Perusahaan yang ingin memperoleh laba serta dapat bertahan selama bertahun-tahun dengan tumbuh dan berkembang tidak boleh menggantungkan diri pada cara kerja perusahaan sendiri yang kurang efisien. Perusahaan harus mengelola usahanya dengan menggunakan manejemen yang baik, sehingga perusahaan dapat bertahan hidup dan berkembang dimasa yang akan datang.

Keadaan dunia usaha berubah
seiring dengan perubahan selera


konsumen dan perubahan yang terjadi pada lingkungan sekitarnya. Situasi pasar yang berubah setiap saat sulit untuk diramalkan dan dipastikan di masa mendatang khususnya di bidang industri makanan. Hal ini membuat industri makanan menjadi salah satu bisnis yang sangat berkembang,karena jumlah penduduk Indonesia dari tahun ke tahun yang terus meningkat menyebabkan kebutuhan masyarakat terhadap pangan semakin meningkat pula. Semakin meningkatnya kebutuhan pangan tersebut, mendatangkan peluang-peluang bisnis yang dapat ditangkap oleh masyarakat Indonesia, salah satunya adalah bisnis makanan. Bisnis ini banyak diminati oleh masyarakat karena dianggap memiliki tingkat pengembalian modal yang relatif tinggi Hal ini terlihat dari semakin banyaknya jumlah usaha makanan yang berhasil dan berkembang, pesatnya industri makanan tersebut terus menggairahkan minat pengusaha untuk menggarap bisnis makanan. Dalam industri makanan banyak sekali bentuk dan macam-macam aneka ragam makanan dari yang kecil hingga yang besar dan dari yang murah hingga sampai yang mahal di pasaran. Di Buleleng makanan-makanan yang tersedia di pasaran sangat beraneka ragam, tetapi umumnya makanan tersebut bukanlah makanan yang khas Bali, serta harga yang ditawarkan belum terjangkau oleh masyarakat. Salah satu makanan tradisional yang cukup sederhana yaitu kue ting-ting sangat cocok untuk dijadikan bisnis usaha makanan.

UD. Kacang Sari adalah salah satu perusahaan yang bergerak dalam bidang industri makanan, yang memproduksi kue kacang ting-ting. UD. Kacang Sari ini terletak di desa Tamblang banjar dinas Kaja Kauh. UD. Kacang Sari berdiri sejak tahun 2000, pernah mengalami kebangkrutan pada tahun 2010. Pada tahun 2014 UD. Kacang Sari kembali memproduksi kue kacang tingting sampai saat ini. Melihat kendala dan masalah yang pernah dihadapi oleh perusahaan, lingkungan eksternal dan internal yang diwujudkan dalam analisis SWOT menjadi faktor penting dalam perkembangan UD.
Kacang Sari dalam membangun dan mengembangkan perusahaanya lagi. Strategi-strategi baru yang inovatif harus dikembangkan untuk memastikan bahwa perusahaan akan melaksanakan tanggung jawab untuk memenuhi kelangsungan perusahaan. Untuk melakukan hal ini, dibutuhkan sebuah pengujian untuk menerapkan analisis SWOT yang akan di gunakan perusahaan.

Analisis Strenght, Weakness, Opportunities, dan Threats (SWOT) adalah analisis terhadap kekuatan, kelemahan, peluang dan ancaman yang di miliki oleh perusahaan dan akan dihadapi oleh perusahaan. Kekuatan adalah sumber daya, keterampilan, atau keungulankeunggulan lainnya yang berhubungan dengan para pesaing dan kebutuhan pasar. Kelemahan adalah keterbatasan atau kekurangan dalam sumber daya, keterampilan dan kapabilitas yang menghambat kinerja dari perusahaan, keterbatasan-keterbatasan tersebut dapat berupa fasilitas yang masih memasarkan barang. Peluang adalah situasi dimana posisi dari perusahaan sangat menguntungkan dalam lingkungan industri, identipikasi segmen pasar yang sebelumnya terabaikan, perubahan pada situasi persaingan atau peraturan, perubahan teknologi, serta membaiknya hubungan pemasok dan pembeli. Ancaman dalam perusahaan adalah situasi dimana posisi dari perusahaan yang sangat tidak menguntungkan dalam lingkungan persaingan. Ancaman merupakan hal yang sangat mengganggu posisi dari perusahaan dan menghambat tujuan perusahaan.

Untuk memaksimalkan persaingan dengan industri-industri lainnya, UD Kacang Sari perlu menerapkan analis SWOT (Strenght, Wekness, Opportunitis, dan Threats) dalam mendistribusikan hasil produksinya ke beberapa wilayah seperti di wilayah desa Tamblang, desa Bangli, serta di desa Kintamani.

Analisis SWOT adalah metode perencanaan strategis yang digunakan untuk mengevaluasi kekuatan (strengths), kelemahan (weaknesses), peluang (opportunities), dan ancaman (threats) dalam suatu perusahaan atau spekulasi 
bisnis. Analisis SWOT dapat diterapkan dengan cara menganalisis dan memilah berbagai hal yang mempengaruhi keempat faktornya, kemudian menerapkannya dalam gambar matrik SWOT, dimana aplikasinya adalah bagaimana kekuatan (strengths) mampu mengambil keuntungan (advantage) dari peluang (opportunities) yang ada, bagaimana mengatasi kelemahan (weaknesses) yang mencegah keuntungan (advantage) dari peluang (opportunities) yang ada, selanjutnya bagaimana kekuatan (strengths) mampu menghadapi ancaman (threats) yang ada, dan terakhir adalah bagaimana cara mengatasi kelemahan (weaknesses) yang mampu membuat ancaman (threats) menjadi nyata atau menciptakan sebuah ancaman baru.

Menurut Daniel Start dan Ingie Hovland 1991 analisis SWOT sebagai instrumen perencanaan strategis yang klasik dengan menggunakan kerangka kerja kekuatan dan kelemahan serta kesempatann eksternal dan ancaman. Instrumen ini memberikan cara sederhana untuk memperkirakan cara terbaik untuk melaksanakan sebuah strategi. Instrumen ini membantu para perencana apa yang bisa dicapai, dan hal-hal apa saja yang perlu diperhatikan oleh mereka. Menurut Rangkuti (2006) analisis SWOT adalah suatu analisis yang didasarkan pada logika yang dapat memaksimalkan kekuatan (strengths) dan peluang (opportunities), namun secara bersamaan dapat meminimalkan kelemahan (weaknesses) dan ancaman (threats)". Bertujuan untuk menentukan usaha yang realistis, sesuai dengan kondisi perusahaan dan oleh sebab itu lebih mudah tercapai setiap perusahaan dapat mempergunakan teknik analisis SWOT. Menurut Griffin (2004) analisis SWOT adalah salah satu langkah yang paling penting dalam memformulasikan strategi, dengan menggunakan misi organisasi sebagai konteks, manajer mengukur kekuatan dan kelemahan internal demikian juga kesempatan dan ancaman eksternal".

Menurut David (2005) SWOT adalah sebagai berikut. Yang pertama Strength (kekuatan) Kekuatan adalah sumber daya, keterampilan, atau keunggulan- keunggulan lain yang berhubungan dengan para pesaing perusahaan dan kebutuhan pasar yang dapat dilayani oleh perusahaan yang diharapkan dapat dilayani. Kekuatan adalah kompetisi khusus yang memberikan keunggulan kompetitif bagi perusahaan di pasar. Yang kedua Weakness (Kelemahan) Kelemahan adalah keterbatasan atau kekurangan dalam sumber daya, keterampilan, dan kapabilitas yang secara efektif menghambat kinerja perusahaan. Keterbatasan tersebut dapat berupa fasilitas, sumber daya keuangan, kemampuan manajemen dan keterampilan pemasaran dapat merupakan sumber dari kelemahan perusahaan. Yang ketiga Opportunities (Peluang) Peluang adalah situasi penting yang menguntungkan dalam lingkungan perusahaan Kecenderungan-kecenderungan penting merupakan salah satu sumber peluang, seperti perubahan teknologi dan meningkatnya hubungan antara perusahaan dengan pembeli atau pemasok merupakan gambaran peluang bagi perusahaan. Yang keempat Threats (Ancaman)Ancaman adalah situasi penting yang tidak menguntungkan dalam lingkungan perusahaan. Ancaman merupakan pengganggu utama bagi posisi sekarang atau yang diinginkan perusahaan. Adanya peraturan-peraturan pemerintah yang baru atau yang direvisi dapat merupakan ancaman bagi kesuksesan perusahaan.Penelitian menunjukkan bahwa kinerja perusahaan dapat ditentukan oleh kombinasi faktor eksternal dan internal. Kedua faktor tersebut harus dipertimbangkan dalam analisis SWOT. Lingkungan Internal strengths dan weaknesses serta lingkungan eksternal opportunities dan threats yang dihadapi dunia bisnis (SWOT). Analisis SWOT membandingkan antara faktor eksternal peluang (opportunities) dan ancaman (threats) dengan faktor internal kekuatan (strengths) dan kelemahan (weaknesses).

Dapat disimpulkan bahwa SWOT adalah proses identifikasi berbagai faktor secara sistematis guna menentukan rumusan yang tepat dan melakukan strategi perusahaan yang terbaik. Analisis 
ini berdasarkan pada logika yang dapat memaksimalkan kekuatan (strengths) dan peluang (opportunities), namun secara bersamaan dapat meminimalkan kelemahan (weaknesses) dan ancaman (threats).

Proses pengambilan keputusan strategis perusahaan selalu berkaitan erat dengan pengembangan misi, visi, tujuan, strategi serta kebijakan perusahaan. Oleh karenanya perencanaan yang strategis sangat memerlukan analisa-analisa dari masing masing SWOT ini (kekuatan, kelemahan, peluang, dan ancaman) di lingkungan perusahaan. Menurut Jogiyanto SWOT (2005:46) "sangat diperlukan dalam menilai kekuatankekuatan maupun kelemahan-kelemahan dari sumber-sumber daya yang dimiliki oleh perusahaan serta menilai kesempatan-kesempatan eksternal maupun tantangan-tantangan yang dihadapi". Menurut Kotler \& Armstrong analisis SWOT (2008:64) "Swot adalah penilaian menyeluruh terhadap kekuatan (strengths), kelemahan (weaknesses), peluang (opportunities), dan ancaman (threats) suatu perusahaan". Analisis ini diperlukan untuk menentukan beberapa strategi yang ada di perusahaan. Salah satunya yang kita bahas adalah strategi promosi dan penempatan produk.

Tujuan analisis SWOT pada perusahaan adalah untuk membenarkan faktor-faktor internal dan eksternal perusahaan yang telah dianalisis. Apabila terdapat kesalahan, agar perusahaan itu berjalan dengan baik maka perusahan itu harus mengolah untuk mempertahankan serta memanfaatkan peluang yang ada secara baik begitu juga pihak perusahaan harus mengetahui kelemahan yang dihadapi agar menjadi kekuatan serta mengatasi ancaman menjadi peluang.

Ketika suatu perusahan mempromosikan suatu produk tentunya pasti telah mengalami proses penganalisaan terlebih dahulu oleh tim teknis corporate plan. Sebagian dari pekerjaan perencanaan strategi terfokus kepada apakah perusahaan mempunyai sumber daya dan kapabilitas memadai untuk menjalankan misinya dan mewujudkan visinya. Pengenalan akan kekuatan yang dimiliki akan membantu perusahaan untuk tetap menaruh perhatian dan melihat peluang-peluang baru. Sedangkan penilaian yang jujur terhadap kelemahan-kelemahan yang ada akan memberikan bobot realisme pada rencana-rencana yang akan dibuat perusahaan.

Maka, fungsi dari analisis SWOT adalah untuk menganalisa mengenai kekuatan dan kelemahan yang dimiliki perusahaan yang dilakukan melalui telaah terhadap kondisi internal perusahaan, serta analisa mengenai peluang dan ancaman yang dihadapi perusahaan yang dilakukan melalui telaah terhadap kondisi eksternal perusahaan.Tidak hanya organisasi profit yang memerlukan pemasaran tetapi organisasi non-profit juga memerlukan pemasaran guna meningkatkan pemasukan dan upaya yang akan dicapai.

Metode analisis SWOT merupakan alat yang tepat untuk menemukan masalah dari empat sisi yang berbeda, dimana aplikasinya adalah bagaimana kekuatan (strengths) mampu mengambil keuntungan dari sebuah peluang (opportunities) yang ada, kemudian bagaimana cara mengatasi kelemahan (weaknesses) yang mencegah keuntungan, selanjutnya bagaimana kekuatan (strengths) mampu menghadapi ancaman (threats) yang ada, dan terakhir adalah bagaimana cara mengatasi kelemahan (weaknesses) yang mampu membuat ancaman (threats) menjadi nyata atau menciptakan sebuah ancaman baru.

Penelitian menunjukkan bahwa kinerja perusahaan dapat ditentukan oleh kombinasi faktor internal dan eksternal. Kedua faktor tersebut harus dipertimbangkan dalam analisis SWOT. SWOT adalah singkatan dari lingkungan internal strength dan weaknesses serta lingkungan eksternal opportunities dan threats yang dihadapi dunia bisnis. Menurut Freddy Rangkuti analisi SWOT membandingkan antara faktor eksternal peluang dan ancaman dengan faktor internal kekuatan dan kelemahan.

Strategi adalah sebuah cara atau pendekatan yang sangat menyeluruh dan 
sangat berkaitan dengan adanya pelaksanaan gagasan atau suatu perencanaan serta eksekusi dalam suatu aktivitas yang berada dalam kurun waktu tertentu. Untuk mendapatkan strategi yang baik tentu saja dibutuhkannya koordinasi atau tim kerja serta mempunyai tema untuk dapat melakukan identifikasi terhadap factor pendukung yang memiliki kesesuaian dengan prinsip untuk melaksanakan pendapat yang sangat rasional atau efisien baik itu dalam pendanaan maupun untuk mendapatkan taktik demi mencapai tujuan yang efektif.

Strategi itu sendiri dibedakan oleh adanya taktik dimana taktik tersebut mempunyai ruang lingkup yang jangkauannya lebih sempit dan juga hanya mempunyai waktu yang lebih singkat meskipun seringkali pada kenyataannya orang mengaitkan kedua kata tersebut. Yang pertama strategi pada awal usaha Strategi ini menyangkut tentang bagaimana cara anda dalam merancang serta memperkenalkan produk baru anda. Oleh sebab itu yang perlu anda lakukan adalah melakukan analisis dan pengamatan terhadap situasi pasar dan kebutuhan masyarakat. Hal ini bertujuan agar barang dan jasa yang anda tawarkan sesuai dan mendapat tanggapan positif dari konsumen. Strategi dalam menangkap peluang pasar. Yang kedua strategi ini berkaitan dengan bagaimana langkah anda dalam membaca atau menciptakan peluang usaha, entah itu berasal dari ide sendiri, ide orang lain, situasi yang muncul, atau bahkan penggabungan dari semua itu. Beberapa orang justru sukses membangun bisnisnya berkatkemampuan dalam melihat kelemahan produk pesaingnya.Yang ketiga strategi Inovasi, Inovasi yang dimaksud menyangkut tentang kemampuan dalam merancang cara untuk menemukan atau menciptakan sesuatu yang unik, menarik, kreatif, dan menjadi solusi terhadap apa yang dibutuhkan konsumen. Yang keempat strategi membidik pasar strategi ini ujga perlu anda perjuangkan karena berkaitan dengan upaya -upaya anda untuk memperebutkan celah pasar yang dirasa potensial susulan perencanaan yang matang, khususnya ketika menjadi persaingan ketat dalam ceruk bisnis tersebut.

Pada saat ini, pentingnya keunggulan sangat besar. Jadi keunggulan adalah tentang bagaimana suatu perusahaan benar-benar dapat menerapkan strategi generik tersebut kedalam prakteknya. Pada dasarnya keunggulan berkembang dari nilai yang perusahaan mampu ciptakan untuk pembelinya. Keunggulan mungkin mengambil bentuk harga yang lebih rendah dibandingkan harga pesaing untuk manfaat yang sesuai atau penyediaan manfaat unik yang lebih sekedar mengimbangi harga premi.

Keunggulan

perusahaan dibandingkan pesaingnya adalah apabila perusahaan dapat memenuhi semua kebutuhan pelanggannya. Untuk tujuan ini perusahaan mempersiapkan berbagai strategi. Dalam bidang Sistem Informasi, Keunggulan Kompetitif berhubungan dengan penggunaan informasi untuk memperoleh pengaruh di pasar. Dimensidimensi Keunggulan, Keunggulan dapat direalisasikan dalam hal mendapatkan keunggulan strategis, taktis, maupun operasional. Pada tingkat manajerial yang tertinggi adalah tingkat perencanaan strategis, sistem informasi dapat digunakan untuk megubah arah sebuah perusahaan dapat mendapatkan keunggulan strategisnya. Pada tingkat kendali manajemen (menengah), manajer dapat memberikan spesifikasi mengenai bagaimana rencana strategis akan diimplementasikan, ehingga menciptakan suatu keunggulan taktis. Pada tingkat kendali operasional (lebih rendah), manajer dapat menggunakan teknologi informasi dalam berbagai pengumpulan data dan penciptaan informasi yang akan memastikan efisiensi operasi, sehingga mencapai keunggulan operasional.

Kesimpulannya, para Manajer perusahaan harus menggunakan sumber daya konseptual (data dan informasi) dan sumber daya fisik dalam mencapai tujuan strategis perusahaan.

Yang pertama aliran Sumber Daya Fisik, adalah aliran dalam sistem informasi dalam bentuk fisik, contoh: Karyawan, Bahan Baku, Mesin dan Uang. Yang kedua 
aliran Sumber Daya Konseptual, adalah aliran dasar atau elemen yang mendasari suatu sistem, seperti Data, Informasi dan Keputusan Sistem informasi dapat mencapai keunggulan kompetitif pada tiga tingkatan yaitu : keunggulan strategis, keunggulan taktis dan keunggulan operasional.

Yang pertama keunggulan Strategis Keunggulan strategis (strategic advantage) adalah keunggulan yang memiliki dampak fundamental dalam membentuk operasi perusahaan.Sistem informasi dapat digunakaan untuk mencapai keunggulan stratergis. Manajer pada tingkat perencanaan strategis dapat meraih keunggulan strategis dengan mempergunakan sistem informasi untuk membedakan perusahaannya dan para pesaing. Tingkat strategis akan menentukan arah dan tujuan perusahaan, namun tetap masih terdapat kebutuhan akan suatu rencana yang dapat mencapai suatu strategis yang menyadari arti penting dari keamanan. Secara singkat Keunggulan adalah keunggulan mendasar yang dipilih oleh perusahaan melalui pemilihan bentuk operasonal perusahaan. Fokus pada keamanan (security) Keputusan keunggulan strategis adalah menjadikan sistem informasi perusahaan tersedia bagi para pelanggan untuk meningkatkan layanan pelanggan. Yang kedua keunggulan Taktis Sebuah perusahaan mendapatkan keunggulan taktis (tactical advantage) ketika perusahaan tersebut mengimplementasikan strategi dengan cara yang lebih baik dari para pesaingnya. Manajer tingkat pengendalian manajemen (tingkat menengah) dapat meraih keunggulan taktis dengan mengarahkan perancangan sistem informasi yang memiliki alat penghubung umum, seperti browser web untuk mengakses internet, yang memungkinkan pelanggan memiliki akses langsung atas informasi. Perusahaan mengembangkan suatu sistem informasi taktis yang tidak hanya akan meningkatkan kepuasan pelanggan, namun juga akan meingkatkan profitabilitas. Tegasnya, keunggulan taktikal atau keunggulan teknikal adalah metode membuat dan menyempurnakan strategi menggunakan cara yang lebih baik dibandingkan dengan cara yang digunakan oleh pesaing. Yang ketiga keunggulan Operasional Keunggulan operasional (operational advantage) adalah suatu keunggulan yang berhubungan dengan transaksi dan proses sehari-hari. Disinilah sistem informasi akan berinteraksi secara langsung dengan proses. Manajer pada tingkat pengendalian operasional (tingkat paling rendah) dapat meraih keunggulan opersional dengan mengembangkan sistem informasi yang menawarkan produk-produk komplementer ketika pelanggan mengakses pesanan mereka sebagai salah satu cara untuk secara bersamaan meningkatkan penjualan dan mendukung kepuasan pelanggan. Singkatnya Kenggulan Operasional adalah keunggulan dalam melakukan pelayanan maksimal. Atau keunggulan operasional adalah keunggulan yang berhubungan dengan transaksi dan proses sehari-hari. Ketika tiga tingkatan diatas bekerja untuk mencapai tujuan yang sama, maka perusahaan akan dapat meraih potensi keuntungan yang paling besar. Sistem informasi yang terpegaruh oleh ketiga tingkat ini akan memiliki kemungkinan terbaik untuk meningkatkan kinerja sebuah perusahaan secara substansial.

\section{METODE}

Peneliti dalam melaksanakan penelitian ini menggunakan rancangan penelitian deskritif, penelitian deskritif adalah metode penelitian yang digunakan untuk menemukan pengetahuan yang seluasluasnya terhadap objek penelitian pada suatu masa tertentu. Penelitian ini di gunakan karena mampu menggambarkan strategi apa yang tepat untuk meningkatkan keunggulan pada UD. Kacang Sari dalam menghadapi persaingan global. Hal ini sejalan dengan pendapat Bogdan dan Taylor (dalam Moloeng, 2004) yang mengemukakan bahwa prosedur penelitian menghasilkan data deskritif berupa kata atau lisan dari orang-orang dan prilaku yang dapat diamati. Penelitian ini dilakukan di UD. Kacang Sari yang berlokasi di desa 
Tamblang, Kecamatan Kubutambahan, Kabupaten Buleleng, Bali

Jenis penelitian yang dilakukan adalah penelitian deskritif. Penelitian ini akan menggambarkan atau memaparkan analisis SWOT dalam penentuan strategi bersaing pada UD. Kacang Sari. Penelitian yang didukung melalui pengumpulan data melalui teknik wawancara (interview) dan pengamatan (observasi).

Metode pengumpulan data yang digunakan dalam penelitian ini adalah. Yang pertama Observasi (pengamatan). Kegiatan Observasi bertujuan untuk mendapatkan gambaran tentang kehidupan sosial yang sulit diketahui dengan metode-metode lainnya. Observasi yang kita lakukan akan dapat memberikan kejelasan tentang sebuah permasalah dan kemudian mencari solusi untuk masalah tersebut. Observasi yang dilakukan bertujuan guna mendapatkan data atau imformasi dimana peneliti melakukan pengamatan langsung terhadap UD. Kacang Sari untuk memperoleh data atau imformasi yang dibutuhkan dalam penelitian ini. Fokus pengamatan tertuju pada keunggulan yang dimiliki oleh perusahaan, kelemahan yang menjadi faktor penghambat perusahaan, peluang dimasa yang akan datang dan ancaman yang akan dihadapi oleh perusahaan. Yang kedua metode wawancara dimana pada penelitian ini menggunakan wawancara tidak berstruktur guna memberikan pemilik perusahaan dan karyawan kebebasan saat menjawab dan tidak terikat pilihanpilihan yang membuat mereka bingung. Metode ini digunakan untuk memperoleh imformasi mengenai keunggulan dan kelemahan yang dimiliki oleh UD. Kacang Sari, peluang dimasa yang akan datang serta bagaimana strategi dalam mempertahankan eksistensinya dan ancaman yang akan dihadapi oleh UD. Kacang Sari.

Analisis data yang digunakan dalam penelitian ini adalah. Yang pertama analisis IFAS dimana analisis IFAS digunakan untuk menganalisis lingkungan internal perusahaan, melalui pendekatan fungsional sehingga dapat diidentifikasikan sejauh mana kekuatan dan kelemahan di daerah-daerah fungsional perusahaan, dan juga untuk memberikan suatu basis bagi pengidentifikasian dan pengevaluasian hubungan di antara daerah-daerah tersebut. IFAS matriks dikembangkan dalam lima tahap, yaitu. Yang pertama membuat daftar critical success factor seperti yang telah diidentifikasikan pada internal audit process sekitar 10-20 faktor internal, termasuk faktor kekuatan rasio dan angka komparatif. Yang kedua memberi bobot nilai pada masing- masing faktor mulai dari 0,0 (tidak penting) sampai 1,0 (sangat penting) bagi masing-masing faktor. Nilai bobot menunjukkan kepentingan relatif dari faktor tersebut untuk menjadi sukses dalam industri perusahaannya. Faktorfaktor yang dipertimbangkan untuk memiliki peran yang paling besar pada prestasi organisasi diberikan nilai tertinggi, demikian pula sebaliknya. Jumlah seluruh bobot harus 1. Yang ketiga memberi rating (nilai) antara 1-4 bagi masing-masing faktor untuk menunjukkan apakah faktor tersebut mempunyai kelemahan yang besar (rating 1), kelemahan yang kecil (rating 2), kekuatan yang kecil (rating 3), kekuatan yang besar (rating 4). Jadi sebenarnya rating mengacu kepada perusahaan, sedangkan bobot mengacu pada industri dimana perusahaan itu berada. Yang keempat kolom bobot dan rating dari masing-masing faktor untuk menentukan skornya. Yang kelima jumlah total skor masing-masing variabel, nilainya merupakan nilai bagi organisasi dari sisi IFAS matriks. Yang kedua analisis EFAS digunakan untuk menganalisis berbagai hal yang menyangkut persoalan ekonomi, sosial budaya, demografi lingkungan, politik, pemerintahan, hukum, teknologi, informasi tentang persaingan di pasar industri dimana perusahaan itu berada. Sebelumnya perlu diketahui disini bahwa penentuan scoring dan critical success factor angkanya bebas, yang dipentingkan disini bahwa skor tersebut menunjukkan besarnya pengaruh (dampak) dari masing- masing faktor tersebut terhadap perusahaan yang bersangkutan. Ada lima tahap pengembangan EFAS matriks, yaitu. Yang pertama membuat critical success 
factor yang diidentifikasikan dalam eksternal audit process yang mencakup perihal peluang dan ancaman. Critical success factor tersebut dibuat secara spesifik dengan menggunakan teknik statistik seperti prosentase, rasio dan perbandingan jika memungkinkan. Yang kedua menentukan bobot critical success factor dengan skala mulai dari 0,0 (tidak penting) sampai 1,0 (sangat penting). Bobot yang diberikan mencerminkan persepsi tentang pentingnya suatu faktor tertentu dibandingkan dengan faktor yang lain. Yang ketiga setiap critical success factor diberi rating antara 1-4. Yang keempat mengalikan antara bobot dan nilai ratingnya untuk mendapat skor untuk semua critical success factor. Yang kelima menjumlahkan skor untuk mendapatkan nilai skor total untuk perusahaan sudah tentu bahwa dalam EFAS matriks kemungkinan nilai terbesar adalah 4,0 dan nilai terendah adalah 1,0. Total skor 4,0 berarti bahwa perusahaan merespon peluang yang ada dengan cara yang luar biasa dan menghindari ancaman-ancaman di pasar industrinya. Total skor sebesar 1,0 berarti strategistrategi perusahaan tidak memanfaatkan peluang-peluang atau tidak menghindari ancaman-ancaman eksternal.

\section{HASIL DAN PEMBAHASAN Hasil}

Kekuatan dalam menentukan keunggulan pada UD. Kacang Sari Desa Tamblang dianalisis dengan menggunakan analisis faktor internal (Internal Factor Analisis Summary). Kelemahan dalam menentukan keunggulan pada UD. Kacang Sari Desa Tamblang dianalisis dengan menggunakan analisis faktor internal (Internal Factor Analisis Summary).

\section{Pembahasan}

Hasil analisis dalam penelitian ini menunjukkan bahwa kekuatan memiliki nilai total sebesar 1,40 berbanding kelemahan sebesar 0,70. Posisi perusahaan terhadap lingkungan di luar juga memiliki posisi yang kuat dimana peluang perusahaan memilik nilai total sebesar 2,30 bebanding ancaman sebesar 0,70. Kekuatan dalam menentukan keunggulan UD. Kacang Sari adalah kue ting-ting (konteng) memiliki kualitas tinggi dengan rasa yang enak gurih dan rasa manis, jaringan pemasaran ke luar desa Tamblang dengan pengiriman produk sampai ke pasar Kintamani, Bangli, Singaraja, dan Denpasar, kondisi keuangan stabil karena tidak memilik pinjaman di bank, reputasi yang baik dalam pelayanan,baik pengiriman karena pengiriman saat tepat waktu sampai di tujuan dan kualitas barang tidak ada yang rusak sampai di tujuan. Kelemahan dalam menentukan keunggulan pada UD. Kacang Sari adalah masih menggunakan kerja manual sehingga mengurangi volume produksi, modal produksi masih kecil sehingga mengurangi jumlah pesanan sedangkan pesanan semakin meningkat, karyawan libur saat ada upacara sehingga proses produksi terganggu dan pengiriman juga terganggu, volume produksi belum maksimal karena ditentukan dengan besarnya pesanan dari pasar. Peluang dalam menentukan keunggulan pada UD. Kacang Sari adalah pemasaran tidak hanya di desa Tamblang Saja produk juga dipasarkan di pasar Kintamani, pasar Bangli, pasar Denpasar,dan pasar Singaraja, minat terhadap kue ting-ting (konteng) sangat baik, harga sangat bersaing dengan kue produk - produk lain, adanya kenaikan pesanan di pasar Kintamani, pasar Denpasar, pasar Bangli, Dan di pasar Singaraja. Ancaman dalam menentukan keunggulan pada UD. Kacang Sari adalah munculnya pesaing dari produk lain seperti kue pia, kue apem yang bisa mengurangi minat terhadap kue ting-ting, pesaing bersaing dengan cara yang tidak sehat seperti merusak nama baik produk, adanya usaha lain sehingga karyawan lebih memilih profesi lain yang lebih menguntungkan dan mengurangi jumlah produk kue ting-ting, produk banyak yang kedaluwarsa sehingga akan mengakibatkan konsumen tidak akan mau lagi mengosumsi kue ting-ting dan mengurangi minat terhadap kue ting-ting itu

sendiri. 
Analisis SWOT adalah suatu analisis yang didasarkan pada logika yang dapat memaksimalkan kekuatan (strengths) dan peluang (opportunities), namun secara bersamaan dapat meminimalkan kelemahan (weaknesses) dan ancaman (threats)". Bertujuan untuk menentukan usaha yang realistis, sesuai dengan kondisi perusahaan dan oleh sebab itu lebih mudah tercapai setiap perusahaan dapat mempergunakan teknik analisis SWOT.

\section{SIMPULAN DAN SARAN \\ Simpulan}

Dari hasil penelitian yang telah dilakukan, maka kesimpulan yang dapat diambil atas penentuan keunggulan melalui analisis SWOT dengan melakukan analisis SWOT yang dilakukan di UD. Kacang Sari Desa Tamblang, sebagai berikut. Kekuatan produksi UD. Kacang Sari meliputi, kue ting-ting (konteng) memiliki kualitas tinggi dengan rasa yang enak gurih dan rasa manis, jaringan pemasaran ke luar Desa Tamblang dengan pengiriman produk sampai ke pasar Kintamani, Bangli, Singaraja, dan Denpasar,kondisi keuangan stabil karena tidak memilik pinjaman di bank,reputasi yang baik dalam pelayanan,baik pengiriman karena pengiriman saat tepat waktu sampai di tujuan dan kualitas barang tidak ada yang rusak sampai di tujuan. Kelemahan produksi UD. Kacang Sari meliputi,. masih menggunakan kerja manual sehingga mengurangi volume produksi,modal produksi masih kecil sehingga mengurangi jumlah pesanan sedangkan pesanan semakin meningkat,karyawan libur saat ada upacara sehingga proses produksi terganggu dan pengiriman juga terganggu, volume produksi belum maksimal karena ditentukan dengan besarnya pesanan dari pasar. Peluang produksi UD. Kacang Saari meliputi, pemasaran tidak hanya di Desa Tamblang Saja produk juga dipasarkan di pasar Kintamani, pasar Bangli, pasar Denpasar,dan pasar Singaraja, minat terhadap kue ting-ting (konteng) sangat baik,harga sangat bersaing dengan kue produk - produk lain,adanya kenaikan pesanan di pasar Kintamani, pasar
Denpasar, pasar Bangli, Dan di pasar Singaraja. Ancaman produksi UD. Kacang Sari meliputi, munculnya pesaing dari produk lain seperti kue pia, kue apem yang bisa mengurangi minat terhadap kue tingting, pesaing bersaing dengan cara yang tidak sehat seperti merusak nama baik produk, adanya usaha lain sehingga karyawan lebih memilih profesi lain yang lebih menguntungkan dan mengurangi jumlah produk kue ting-ting, produk banyak yang kedaluwarsa sehingga akan mengakibatkan konsumen tidak akan mau lagi mengosumsi kue ting-ting dan mengurangi minat terhadap kue ting-ting itu sendiri.

\section{Saran}

Berdasarkan hasil penelitian yang sudah dilakukan, peneliti berpendapat bahwa. Dalam hal produksi ataupun pengiriman, pemilik UD. Kacang Sari dan karyawan hendaknya lebih memperhatikan jumlah produksi karena jumlah pesanan semakin meningkat di luar desa Tamblang, dan pemilik dari UD. Kacang Sari memberi jumlah barang yang lebih dari jumlah sebelumnya kepada semua pasar karena melihat dari jumlah pesanan yang semakin meningkat di setiap pasar luar desa Tamblang. Dalam hal pengiriman hendaknya karyawan lebih memperhatikan barang yang telah dikirim supaya barang tidak rusak sampai di tujuan dan minat terhadap kue ting-ting menjadi lebih banyak.

\section{DAFTAR PUSTAKA}

David, F. R. (2007). Manajemen Strategis. Jakarta: Salemba Empat.

Griffin, M. (2004). Manajemen. Jakarta. Salemba Empat.

Irawan, (2008) Manajemen pemasaran Modern. Yogyakarta: Liberty.

J. David Hunger, T. L. (2003). Manajemen Strategi. yogyakarta: Airlangga.

Jogiyanto 2005. Analisis dan Desain Sistem Imformasi. Yogyakarta: Andi

Kotler, P. (1999). Manajemen Pemasaran di Indonesia. jakarta: Salemba 
Empat. Kuncoro, M. (2003).

Metode Riset Untuk Untuk Bisnis

Dan Ekonomi. Jakarta: Erlangga.

Rangkuti, F. (2006). Analisis SWOT Teknik

Membedah Kasus Bisnis. Jakarta:

Gramedia Pustaka Utama

Sunarto. 2004. Anggaran

Perusahaan. Yogyakarta : amus. 
